\title{
Pathogenic Fungi Associated with Soursop Fruits (Annona muricata L.) during Postharvest in Nayarit, Mexico
}

\author{
Alejandra Verónica González-Ruíz ${ }^{1,2}$, Yolotzin Apatzingan Palomino-Hermosillo ${ }^{2}$, Rosendo Balois-Morales ${ }^{1,2}$, \\ Verónica Alhelí Ochoa-Jiménez ${ }^{2}$, Paloma Patricia Casas-Junco ${ }^{2}$, Graciela Guadalupe López-Guzmán ${ }^{3}$, \\ Guillermo Berumen-Varela ${ }^{2}$ ad and Pedro Ulises Bautista-Rosales ${ }^{1,2, *(D)}$
}

1 Programa de Maestría en Ciencias Biológico Agropecuarias, Universidad Autónoma de Nayarit, Km 9 Carretera Tepic-Compostela, C.P. 63780 Xalisco, Nayarit, Mexico; gt16_fan@hotmail.com (A.V.G.-R.); rmbalois@uan.edu.mx (R.B.-M.)

2 Unidad de Tecnología de Alimentos, Secretaría de Investigación y Posgrado, Universidad Autónoma De Nayarit, Ciudad de la Cultura S/N, C.P. 63000 Tepic, Nayarit, Mexico; yolotzin@uan.edu.mx (Y.A.P.-H.); veronica.ochoa@uan.edu.mx (V.A.O.-J.); paloma.casas@uan.edu.mx (P.P.C.-J.); guillermo.berumen@uan.edu.mx (G.B.-V.)

3 Unidad Académica de Agricultura, Universidad Autónoma de Nayarit, Km. 9 Carretera Tepic-Compostela, C.P. 63780 Xalisco, Nayarit, Mexico; graciela.lopez@uan.edu.mx

* Correspondence: ubautista@uan.edu.mx; Tel.: +52-3112-1188-51

Citation: González-Ruíz, A.V.; Palomino-Hermosillo, Y.A.; Balois-Morales, R.; Ochoa-Jiménez, V.A.; Casas-Junco, P.P.; López-Guzmán, G.G.; Berumen-Varela, G.; Bautista-Rosales, P.U. Pathogenic Fungi Associated with Soursop Fruits (Annona muricata L.) during Postharvest in Nayarit, Mexico. Horticulturae 2021, 7, 471. https://doi.org/10.3390/horticulturae 7110471

Academic Editors: Igor Maksimov and Oksana Lastochkina

Received: 3 October 2021

Accepted: 2 November 2021

Published: 5 November 2021

Publisher's Note: MDPI stays neutral with regard to jurisdictional claims in published maps and institutional affiliations.

Copyright: (c) 2021 by the authors. Licensee MDPI, Basel, Switzerland. This article is an open access article distributed under the terms and conditions of the Creative Commons Attribution (CC BY) license (https:// creativecommons.org/licenses/by/ $4.0 /)$.
Abstract: Nayarit ranks first in national soursop production (Annona muricata L.). However, the soursop fruits are perishable and susceptible to microorganisms attack, reaching up to $60 \%$ of the postharvest losses. Due to the previously mentioned points, the objective of the present study was to isolate, identify, and determine the pathogenicity of fungi related to postharvest diseases in soursop fruits in the main producing areas of Nayarit, Mexico. Several fungi belonging to the genera Fusarium sp., Rhizopus, Lasiodiplodia, Gliocladium, and Colletotrichum were isolated and morphologically identified. Further, bioinformatics sequence analysis of the ITS1-5.8S-ITS2 region of the rDNA identified that most pathogen species were Lasiodiplodia theobromae, Lasiodiplodia pseudotheobromae, and Nectria haematococca, which cause postharvest diseases in soursop fruit, affecting their quality. Lasiodiplodia causes the highest postharvest damage in soursop among the pathogenic species identified.

Keywords: Lasiodiplodia theobromae; Lasiodiplodia pseudotheobromae; Nectria haematococca; pathogenicity; postharvest diseases

\section{Introduction}

In Mexico, the soursop (Annona muricata L.) is the most important agricultural crop of the Annonaceae family [1]. In 2018, Agri-Food and Fisheries Information Service reported a total production of 29,228.06 $\mathrm{t}$ of the fruit, producing 21,860.02 $\mathrm{t}$ in Nayarit [2]. Indeed, Nayarit is one of the leading producers of this fruit, followed by Colima and Michoacán, which together produce $85 \%$ of soursop [3].

The Annona genus comprises about 120 species of the tropical and subtropical climate. According to the Integrated Taxonomic Information System (SSIT-CONABIO), 13 genera and 37 species of the Annonaceae family have been located in Mexico [3]. The soursop tree is native to the countries of the Caribbean, Brazil, and Mexico. The tree is 4 to $8 \mathrm{~m} \mathrm{high,}$ and sometimes, it reaches up to $10 \mathrm{~m}$ [4]. It develops in hot and humid climates between $23{ }^{\circ} \mathrm{C}$ and $30{ }^{\circ} \mathrm{C}[5]$.

The fruit can reach up to $40 \mathrm{~cm}$ long, weighing between 2 and $4 \mathrm{~kg}$ [4]. The peel is covered with soft spines, it is bright dark green, and it turns matt green when ripe. The pulp is white and juicy with a bittersweet, fibrous taste, delicate aroma, and high nutrient content [6]. The fruit has black seeds inside that are 1.25 to $2 \mathrm{~cm}$ long [7]. Pests (Bephratelloides cubensis, Cerconota anonella, Optatus palmaris, Oenomaus ortygnus, Maconellicocus hirsutus, Planococcus citri, and Gonodonta pyrgo) and diseases (anthracnose, descending death of 
the branches, and fruit rot) are limiting factors in the production of fruit trees in Mexico. The high number of pests may be due to volatile compounds, which could attract them. Another important factor is the weather, since soursop fruit and flower could have a high incidence ( $>50 \%$ ) of fungi during the rainiest months (July to October) [1]. Furthermore, soursop fruit is prone to phytosanitary problems, and one of these problems is the damage caused by phytopathogenic fungi during postharvest due to storage conditions and the variety of the fruit, which could cause black spots and restrict the soursop cultivation and commercialization $[1,8]$. Pests and diseases have a high impact on the yield and quality of the crop, causing economic losses. In Nayarit, $94 \%$ of the losses are associated with pests and diseases that attack the crop, while the remaining $6 \%$ is due to fruit softening and susceptibility to bruising and wounds during ripening [9].

One of the primary diseases that attack the soursop fruit is the anthracnose produced by the fungus Colletotrichum gloeosporioides Penz, which damages seedlings and adult plants by attacking stems, branches, leaves, flowers, and fruits [3]. Other diseases such as soft rot (Rhizopus stolonifer Ehr.), black leaf spot (Phyllosticta sp.), leaf apex spot (Pestalotia sp.), white leaf spot (Macrophoma sp.), fruit rot (Fusarium sp., Lasiodiplodia theobromae), purple spot (Phytophthora sp.), branch drying (Diplodia sp.), leaf spot (Scolecotrichum sp.), and descending death (Lasiodiplodia theobromae) are also reported in Mexico [1,2,10]. However, there are no reports of the search for pathogens during postharvest in Nayarit. Therefore, this work aimed to isolate, identify, and determine the pathogenicity of fungi-related diseases postharvest soursop fruits in the main producing areas of Nayarit state.

\section{Materials and Methods}

\subsection{Plant Material}

Soursop fruits of $500 \mathrm{~g}$ on average were collected in traditional orchards located in Tecuitata, San Blas $\left(21^{\circ} 27^{\prime} 06.99^{\prime \prime}\right.$ N; $105^{\circ} 08^{\prime} 44^{\prime \prime}$ W, 220 m.a.s.l.), El Tonino, Compostela $\left(21^{\circ} 14^{\prime} 14^{\prime \prime} \mathrm{N}\right.$; $104^{\circ} 54^{\prime} 04^{\prime \prime}$ W, 301 m.a.s.l.), and Venustiano Carranza, Tepic $\left(21^{\circ} 32^{\prime} 2.77^{\prime \prime} \mathrm{N}\right.$; $104^{\circ} 58^{\prime} 39.73^{\prime \prime}$ W, 893 m.a.s.l.) in Nayarit, Mexico. The sampling sites are located in the central, central coast, and south coast; these regions are the main production areas of soursop, with $99 \%$ of the state production [2]. Three farms were sampled in each region and 10 fruits were collected in each farm. Fruits were manually harvested at physiological maturity (150 days post-anthesis, and the fruit turned light green or green-yellowish) [8], without visible mechanical damage or signs of disease, and then transported to laboratory. The fruits were harvested in August, during the rainfall season.

\subsection{Fungi Isolation}

Fruits were washed, disinfected, and then incubated in Climacell ${ }^{\circledR}$ air conditioning chamber (MMM group $\odot$, Planegg, BY, Germany) at $28 \pm 2{ }^{\circ} \mathrm{C}$ with a relative humidity of $90 \pm 5 \%$ to stimulate the development of the diseases. Once the fruits showed signs of disease, tissue segments (epicarp and mesocarp) of $1 \mathrm{~cm}^{2}$ (50\% healthy tissue and 50\% diseased tissue) were taken. These samples were disinfected with $1 \%$ sodium hypochlorite solution for $2 \mathrm{~min}$, rinsed with sterile distilled water, and transferred to dry on sterile filter paper [11]. Tissue fractions were placed in potato dextrose agar (PDA) culture medium and incubated at $25^{\circ} \mathrm{C}$ for 3-8 days. Subsequently, the strains were purified on PDA agar.

\subsection{Morphological Characterization of Fungi}

The macroscopic morphological characterization of the isolated fungi was performed by observing the appearance and color in vitro of the isolated colonies. The microscopic morphology was performed by microcultures in Petri dishes with wet gauze, glass rods folded in " $\mathrm{V}$ ", and sterile objects. $3 \mathrm{~mL}$ of PDA medium was added to a slide and inoculated with the isolated fungi. Microcultures were incubated for $1-3$ days at $28^{\circ} \mathrm{C}$. We added drops of lactophenol blue: glycerol (1:1) to observe the morphology of the fungi. The characteristics of the mycelium, conidiophores, and conidia were observed with an optical microscope with $10 \times$ and $40 \times$ objectives, and images were obtained using the Motic 
Images Plus 2.0 software (Motic $\odot$, Hong Kong, KLN, China). After, microorganisms were identified through taxonomic keys and morphological descriptions for fungi made by Agrios [11], Barnett and Hunter [12], and Watanabe [13]. On the other hand, fungi were classified by their growth rate as fast, medium, and slow. It was considered fast-growing if it developed in more than $90 \%$ in a Petri dish with PDA at $72 \mathrm{~h}$ of incubation. If $90 \%$ of the development was reached after eight days, it was considered slow growth.

\subsection{Pathogenicity Tests}

Soursop fruits at physiological maturity, without mechanical damage and signs of disease, were washed and disinfected with $1.5 \%$ sodium hypochlorite for $3 \mathrm{~min}$. Then, wounds were made with a bodkin to generate cavities $1 \mathrm{~mm}$ deep in areas of the fruit and inoculated with the fungi mycelium [14].

The inoculated soursop fruits were placed in Climacell ${ }^{\circledR}$ air conditioning chamber (MMM group $\odot$, Germany), with a relative humidity of $90 \%$ and at $28{ }^{\circ} \mathrm{C}$ for 5 days. The lesions were measured vertically, horizontally, and diagonally to later calculate the average of the measurements. Subsequently, tissue samples were taken with signs of pathogenesis and cultured in PDA for re-isolation and identification. The experiment was done in sextuplicate. The results were analyzed using an analysis of variance (ANOVA), and the Tukey test $(p<0.05)$ was used to determine the statistical differences among treatments.

\subsection{Molecular Identification}

Molecular identification of fungi with higher pathogenic capacity was performed.

\subsubsection{Extraction of DNA}

The DNA extraction was performed using the CTAB technique of Allers and Lichten [15] with modifications. A volume of $700 \mu \mathrm{L}$ of CTAB I solution (1 M Tris Base, $0.5 \mathrm{M}$ EDTA $\mathrm{pH} 8,5 \mathrm{M} \mathrm{NaCl}, 2 \% \mathrm{CTAB}, 0.5 \% \mathrm{PVP}), 0.3 \mathrm{~g}$ of mycelium, and $1 \mathrm{~mm}$ diameter glass beads in Vortex-Genie pulse ${ }^{\circledR}$ were mixed (Scientific industries ${ }^{\mathrm{TM}}$, Bohemia, NY, USA) for $10 \mathrm{~min}$ at maximum speed. Then, it was incubated at $65^{\circ} \mathrm{C}$ for one $\mathrm{h}$ in Accublock ${ }^{\mathrm{TM}}$ (Labnet International Inc, Edison, NJ, USA) and then allowed to cool at room temperature. Later, $700 \mu \mathrm{L}$ of chloroform: $21: 1 v / v$ isoamyl alcohol was added, gently mixed, and homogenized in the vortex at maximum speed for $30 \mathrm{~s}$. It was centrifuged at $16,000 \times g$ for $10 \mathrm{~min}$ in a MiniSpin ${ }^{\circledR}$ mini centrifuge (Eppendorf, Hamburg, HH, Germany). The supernatant was recovered, and $70 \mu \mathrm{L}$ of CTAB II $(2 \% \mathrm{NaCl}, 5 \% \mathrm{CTAB})$ was added, mixed in a vortex for $30 \mathrm{~s}$ at maximum speed. After, it was centrifuged at $16,000 \times g$ for $10 \mathrm{~min}$. The supernatant was recovered; next, $700 \mu \mathrm{L}$ of chloroform: isoamyl alcohol 21:1 was added and mixed by inversion. It was centrifuged at $16,000 \times g$ for $10 \mathrm{~min}$, and the supernatant recovered. Subsequently, $700 \mu \mathrm{L}$ of cold 2-propanol $\left(-20^{\circ} \mathrm{C}\right)$ was added, mixed by inversion, and allowed to stand for two $h$ at $-20^{\circ} \mathrm{C}$. Then, it was centrifuged at $16,000 \times g$ for $15 \mathrm{~min}$ at $4{ }^{\circ} \mathrm{C}$, the supernatant was decanted, and pellet formation was verified. The pellet was washed with $75 \%$ ethanol. The sample was re-suspended in $50 \mu \mathrm{L}$ of deionized water and stored at $4{ }^{\circ} \mathrm{C}$.

The Synergy ${ }^{\mathrm{TM}}$ HT spectrophotometer (Biotek ${ }^{\circledR}$, Winooski, VT, USA) was used to quantify and determine the purity of the samples. Two microliters of DNA were added to the reading plate, and the purity of the genomic DNA was determined using the A260/280 ratio. Finally, the DNA was visualized by $1 \%$ agarose gel electrophoresis. Samples were stored at $-85^{\circ} \mathrm{C}$ until use.

\subsubsection{Polymerase Chain Reaction (PCR) Conditions}

Molecular identification was performed through the ITS1-5.8S-ITS2 region of the rDNA using the ITS1 (5'-TCCGTAGGTGAACCCTGCGG-3') and ITS4 (5'-TCCTCCGCTTA TTGATATGC- $3^{\prime}$ ) primers. In addition, the $18 \mathrm{~s}$ subunit of the rDNA was amplified with the primers NS3 (5'-GCAAGTCTGGTGCCAGCAGCC- $\left.{ }^{\prime}\right)$ and NS6 (5'-GCATCACAGACCTGT TATTGCCTC- $\left.3^{\prime}\right)$. Moreover, the primers NL1 (5'-GCATATCAATAAGCGGAGGAAAAG$\left.3^{\prime}\right)$ and NL4 (5'-GGTCCGTGTTTCAAGACGG-3'), designed to amplify the D1/D2 domains 
of the 26S region of the rDNA were used. The PCR was performed with the following conditions: denaturation at $94^{\circ} \mathrm{C}$, followed by 35 cycles at $94^{\circ} \mathrm{C}$ for $1 \mathrm{~min}$, alignment for $1 \mathrm{~min}$ at $50^{\circ} \mathrm{C}$, an extension of $1 \mathrm{~min}$ at $72{ }^{\circ} \mathrm{C}$, and a final extension of $10 \mathrm{~min}$ at $72{ }^{\circ} \mathrm{C}$ in BioRad T100 TM Thermal Cycler Block thermal cycler (BioRad, US). PCR products were verified by electrophoresis using a $1 \%$ agarose gel stained with Red Gel, visualized on a Benchtop UV Transilluminator transilluminator $\left(\mathrm{UVP}^{\circledR}, \mathrm{USA}\right)$, and photographed with a PhotoDoc-It ${ }^{\mathrm{TM}}$ Imaging System (UVP ${ }^{\circledR}$, Upland, CA, USA). PCR products were sequenced by Macrogen Inc. (Seoul, Korea). Molecular identification was performed by comparing the sequence obtained against all nucleotide sequences of fungi reported in the NCBI database (National Center for Biotechnology Information; http:/ / www.ncbi.nlm.nih.gov; accessed on 20 January 2021).

\section{Results}

\subsection{Isolation and Morphological Identification}

A total of 33 isolates were obtained from the orchards of the Tonino (10 isolates), Tecuitata (10 isolates), and Venustiano Carranza (13 isolates). The isolates were categorized into five groups according to their morphological characteristics (Figure 1).

\begin{tabular}{|c|c|c|c|c|}
\hline \multirow{2}{*}{ Group } & \multirow{2}{*}{ Isolates } & \multirow{2}{*}{ Genus } & Characteristics & \multirow{2}{*}{$\begin{array}{l}\text { Growth } \\
\text { rate }\end{array}$} \\
\hline & & & Macroscopic & \\
\hline 1 & $\begin{array}{l}\text { TeG1,TeG2, TeG3, TeG4, TeG5, TeG6, TeG7, TeG9, } \\
\text { TeG10, TonG1, TonG2, TonG3, TonG5, TonG6, } \\
\text { TonG7, TonG8, TonG9, TonG10, VcaG2, VcaG6, } \\
\text { VcaG8, VcaG10, VcaG9, VcaG11, VcaG12 }\end{array}$ & Lasiodiplodia & & Fast \\
\hline 2 & TeG8 & Fusarium & & Slow \\
\hline 3 & VcaG1, VcaG5, VcaG7, VcaG13 & Gliocadium & & Medium \\
\hline 4 & TonG4 & Rhizopus & & Fast \\
\hline 5 & VcaG3, VcaG4 & Colletotrichum & & Medium \\
\hline
\end{tabular}

Figure 1. Classifications of pathogens isolated according to their morphological characteristics.

The first group of colonies showed mycelium of rapid growth, white to grayish olive, spongy, and dense, of round cottony shape, with little elevation and filamentous at the edges. Over time, the colonies became black. Regarding microscopic morphology, hyphae were pigmented, thick-walled, and septated. The taxonomic keys and descriptions coincide with the genus Lasiodiplodia [16].

The second group shows cottony round, elevated, with pinkish-white or sometimes violet concentric rings and slow-growing colonies. As for the microscopic morphology, this group had hyaline thin-walled and septate hyphae. Besides, it showed short phyloids, with two to five conidia; these conidia were ovoid, curved, non-septated, or coenocytic. These characteristics correspond to the Fusarium $[12,13,17]$.

The third group of isolates showed a moderate growth rate; the colonies showed white to pinkish coloration, a filamentous round shape, with elevation and concentric rings 
(Figure 1). This group showed hyaline, septate, and branched conidiophores with phyloids in groups of three. The conidia were hyaline, thin-walled round, and in oval clusters. These characteristics coincide with the genus Gliocladium [12,13,18,19].

The fourth group of isolates was characterized by rapid mycelial growth, white and filamentous. Smooth, non-septated, thick-walled sporangiophores were observed. The sporangia were spherical, pigmented, and globose (Figure 1). The sporangiospores were pigmented and showed an oval or round shape. These characteristics are representative of the genus Rhizopus [11-13,20].

The fifth group showed colonies with a moderate mycelial growth rate, white coloration with a salmon center, and concentric rings. Besides, the colonies showed granular texture, without elevation and irregular ends. The hyphae were non-septated, cylindrical, and hyaline. The spores were hyaline, smooth, coenocytic, cylindrical, rounded ends, and showed two internal vesicles (Figure 1). These characteristics are related to the genus Colletotrichum $[12,13,20-23]$.

According to the macro and microscopic morphological features, the isolates corresponded to the genera Lasiodiplodia spp. (76\%), Gliocadium spp. (12\%), Colletotrichum spp. (6\%), Fusarium sp. (3\%), and Rhizopus sp. (3\%).

\subsection{Pathogenicity Test on Soursop (Annona muricate L.)}

All inoculated fruits developed rot symptoms on the fifth day, confirming the pathogenicity of the five genera evaluated with Koch's postulates. The fungi of the genera Lasiodiplodia, Rhizopus, and Fusarium, induced necrotic lesions with soft rot, while Gliocadium and Colletotrichum produced dark brown lesions, with hard and dry rot.

Figure 2 shows the comparison of the damage severity by the fungi on soursop fruits. Significant statistical differences were found among strains $(p<0.05)$; however, TonG5, TonG6, VcaG8, TeG3, TonG9, TonG1, TeG8, TeG4, TeG9, and VcaG10 stood out as the most pathogenic strains (Table 1).
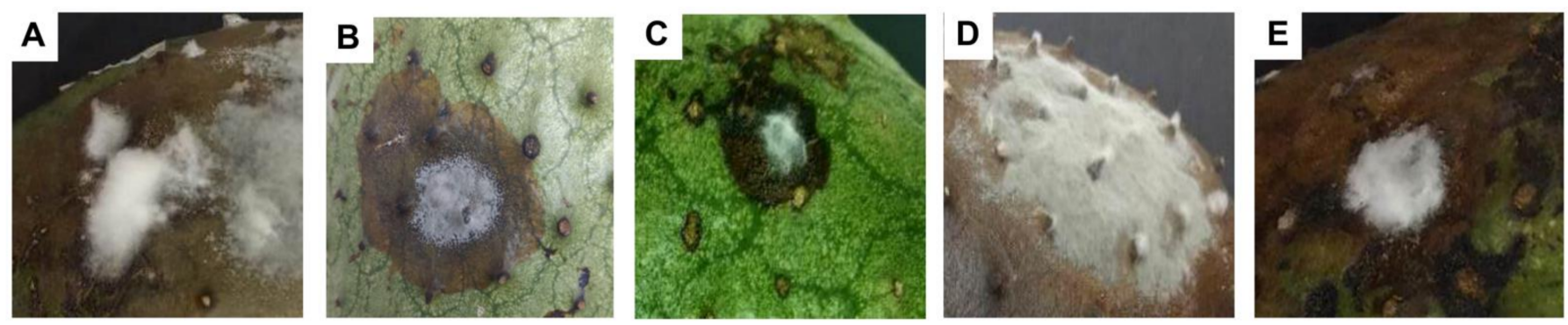

Figure 2. Fruit damage by the fungi. (A) Fusarium sp., (B) Colletotrichum sp., (C) Gliocladium sp., (D) Lasiodiplodia sp., and (E) Rhizopus sp.

Table 1. Severity damage produced by isolated fungi on the soursop fruit.

\begin{tabular}{cc}
\hline Isolates & Severity Damage (mm) \\
\hline TonG5 & $82.66 \pm 7.79^{\text {a }}$ \\
\hline TonG6 & $75.00 \pm 3.4^{\text {ab }}$ \\
\hline TonG9 & $66.66 \pm 10.8^{\text {abcd }}$ \\
\hline TonG1 & $66.12 \pm 1.86^{\text {abcde }}$ \\
\hline TonG7 & $32.00 \pm 4.69^{\text {efghijk }}$ \\
\hline TonG2 & $29.66 \pm 6.63^{\text {fghijkl }}$ \\
\hline TonG8 & $29.33 \pm 4.69^{\text {fghijkl }}$ \\
\hline TonG3 & $8.33 \pm 0.49^{\text {ijkl }}$ \\
\hline
\end{tabular}


Table 1. Cont.

\begin{tabular}{|c|c|}
\hline Isolates & Severity Damage $(\mathrm{mm})$ \\
\hline TonG10 & $9.33 \pm 1.76^{\mathrm{ijkl}}$ \\
\hline TonG4 & $6.50 \pm 1.85^{\mathrm{ijkl}}$ \\
\hline VcaG8 & $71.33 \pm 4.63^{a b c}$ \\
\hline VcaG10 & $49 \pm 14.15^{\text {abcdefdh }}$ \\
\hline VcaG6 & $39.83 \pm 8.16^{\text {cdefghi }}$ \\
\hline VcaG9 & $29.17 \pm 1.43^{\text {fghijkl }}$ \\
\hline VcaG12 & $28.27 \pm 1.73$ ghijkl \\
\hline VcaG3 & $16.33 \pm 8.57^{\text {hijkl }}$ \\
\hline VcaG4 & $9.33 \pm 0.87^{\mathrm{ijkl}}$ \\
\hline VcaG5 & $7.26 \pm 0.50 \mathrm{ijkl}$ \\
\hline VcaG2 & $6.67 \pm 1.42^{\mathrm{ijkl}}$ \\
\hline VcaG13 & $5.50 \pm 0.28^{\mathrm{jkl}}$ \\
\hline VcaG1 & $5.00 \pm 1.15^{\mathrm{kl}}$ \\
\hline TeG3 & $67.00 \pm 2.64$ abcd \\
\hline TeG8 & $63.00 \pm 11.46^{\text {abcdef }}$ \\
\hline TeG4 & $63.33 \pm 11.46^{\text {abcdef }}$ \\
\hline TeG9 & $60.00 \pm 10.53^{\text {abcdefg }}$ \\
\hline TeG1 & $43.70 \pm 13.22^{\text {bcdefgh }}$ \\
\hline TeG6 & $39.30 \pm 10.35^{\text {cdefghij }}$ \\
\hline TeG5 & $37.00 \pm 4.61^{\text {defghijk }}$ \\
\hline TeG7 & $21.33 \pm 8.94$ hijkl \\
\hline TeG10 & $18.17 \pm 5.64$ hijkl \\
\hline TeG2 & $8.00 \pm 1.73 \mathrm{ijkl}$ \\
\hline
\end{tabular}

Standard deviation $( \pm)$. Different letters indicate a significant difference (Turkey's test; $p<0.05$ ).

\subsection{Molecular Identification of Pathogenic Fungi}

The most notable species (according to their pathogenicity to soursop fruits) were molecularly identified as Lasiodiplodia pseudotheobromae, Lasiodiplodia theobromae, and Nectria haematococca. These results corroborate the findings at the macroscopic and microscopic levels. Additionally, the results were the same with each amplified region, showing a high percentage of identity with the compared sequences (Table 2). 
Table 2. Molecular identification of the most pathogenic fungi to soursop fruit.

\begin{tabular}{|c|c|c|c|c|c|c|c|}
\hline \multirow[b]{2}{*}{ Isolated } & \multicolumn{6}{|c|}{ Identification } & \multirow[b]{2}{*}{$\begin{array}{c}\text { Access } \\
\text { Number } \\
\text { (NCBI) }\end{array}$} \\
\hline & ITS $^{a}$ & $\begin{array}{c}\text { Homology } \\
(\%)\end{array}$ & $\mathbf{N L}^{\mathbf{b}}$ & $\begin{array}{c}\text { Homology } \\
(\%)\end{array}$ & NS $^{c}$ & $\begin{array}{c}\text { Homology } \\
\text { (\%) }\end{array}$ & \\
\hline TeG3 & $\begin{array}{c}\text { Lasiodiplodia } \\
\text { pseudotheobromae }\end{array}$ & 99 & $\begin{array}{c}\text { Lasiodiplodia } \\
\text { pseudotheobromae }\end{array}$ & 99 & $\begin{array}{l}\text { Lasiodiplodia } \\
\text { theobromae }\end{array}$ & 98 & OK636411 \\
\hline TeG4 & $\begin{array}{c}\text { Lasiodiplodia } \\
\text { theobromae }\end{array}$ & 99 & $\begin{array}{c}\text { Lasiodiplodia } \\
\text { theobromae }\end{array}$ & 98 & $\begin{array}{l}\text { Lasiodiplodia } \\
\text { theobromae }\end{array}$ & 97 & OK636157 \\
\hline TeG8 & $\begin{array}{c}\text { Nectria } \\
\text { haematococca }\end{array}$ & 97 & $\begin{array}{c}\text { Nectria } \\
\text { haematococca }\end{array}$ & 97 & $\begin{array}{c}\text { Nectria } \\
\text { haematococca }\end{array}$ & 95 & OK636158 \\
\hline TeG9 & $\begin{array}{c}\text { Lasiodiplodia } \\
\text { theobromae }\end{array}$ & 99 & $\begin{array}{c}\text { Lasiodiplodia } \\
\text { theobromae }\end{array}$ & 98 & $\begin{array}{c}\text { Lasiodiplodia } \\
\text { theobromae }\end{array}$ & 98 & OK647292 \\
\hline TonG1 & $\begin{array}{c}\text { Lasiodiplodia } \\
\text { pseudotheobromae }\end{array}$ & 100 & $\begin{array}{c}\text { Lasiodiplodia } \\
\text { pseudotheobromae }\end{array}$ & 99 & $\begin{array}{c}\text { Lasiodiplodia } \\
\text { pseudotheobromae }\end{array}$ & 99 & OK647294 \\
\hline TonG5 & $\begin{array}{c}\text { Lasiodiplodia } \\
\text { theobromae }\end{array}$ & 100 & $\begin{array}{c}\text { Lasiodiplodia } \\
\text { theobromae }\end{array}$ & 99 & $\begin{array}{c}\text { Lasiodiplodia } \\
\text { theobromae }\end{array}$ & 99 & OK636236 \\
\hline TonG6 & $\begin{array}{l}\text { Lasiodiplodia } \\
\text { theobromae }\end{array}$ & 99 & $\begin{array}{l}\text { Lasiodiplodia } \\
\text { theobromae }\end{array}$ & 98 & $\begin{array}{l}\text { Lasiodiplodia } \\
\text { theobromae }\end{array}$ & 99 & OK636403 \\
\hline TonG9 & $\begin{array}{l}\text { Lasiodiplodia } \\
\text { theobromae }\end{array}$ & 100 & $\begin{array}{l}\text { Lasiodiplodia } \\
\text { theobromae }\end{array}$ & 100 & $\begin{array}{l}\text { Lasiodiplodia } \\
\text { theobromae }\end{array}$ & 98 & OK636404 \\
\hline VcaG8 & $\begin{array}{l}\text { Lasiodiplodia } \\
\text { theobromae }\end{array}$ & 99 & $\begin{array}{l}\text { Lasiodiplodia } \\
\text { theobromae }\end{array}$ & 99 & $\begin{array}{l}\text { Lasiodiplodia } \\
\text { theobromae }\end{array}$ & 96 & OK636405 \\
\hline VcaG10 & $\begin{array}{l}\text { Lasiodiplodia } \\
\text { theobromae }\end{array}$ & 99 & $\begin{array}{l}\text { Lasiodiplodia } \\
\text { theobromae }\end{array}$ & 100 & $\begin{array}{l}\text { Lasiodiplodia } \\
\text { theobromae }\end{array}$ & 97 & OK636410 \\
\hline
\end{tabular}

${ }^{a}$ ITS1 and ITS4 primers from the ITS1-5.8S-ITS2 region of the rDNA. ${ }^{b}$ NS3 and NS6 primers from the $18 \mathrm{~S}$ subunit of the rDNA. ${ }^{c}$ NL1 and NL4 primers from the D1/D2 domains of the $26 \mathrm{~S}$ region of the rDNA.

\section{Discussion}

In the present study, five genera that showed pathogenicity to soursop fruits were isolated: Lasiodiplodia, Fusarium, Gliocladium, Rhizopus, and Colletotrichum. These genera are primarily known for invading, penetrating, and colonizing the tissue massively, causing damage and secreting secondary metabolites known as mycotoxins, which can cause allergies and poisonings in consumers. Besides, these fungi can cause alterations in physical appearance, nutritional value, and organoleptic characteristics [24].

The genus Lasiodiplodia is distinguished from other genera by the presence of pycnidia, paraphysis, and longitudinal striations in mature conidia [25-27]. Lasiodiplodia has been reported to cause plant diseases, both pre and postharvest. The cellulolytic activity of this genus of fungi allows the penetration and colonization of the plant in a similar way to that of a fungus that causes soft rot, using starch and other carbohydrates present [21]. Moreover, this pathogen can be associated with latent infections, i.e., it does not develop until the fruit softening associated with ripening. The main form of penetration of this fungus is through physical damage to the fruits. These damages can be caused by insects, birds, fruit handling rodents, insect punctures, and cut stems [1]. These types of damages have been commonly observed in tropical fruits and postharvest stages such as cocoa (Theobroma cacao L.), avocado (Persea americana Mill), papaya (Carica papaya L.), rubber tree (Hevea brasiliensis Muell.), (L. Batsch), and sugarcane (Saccharum officinarum L.) [21,28]. Lasiodiplodia pseudotheobromae fungus has been identified as the causative agent of soft rot in soursop fruits [29].

From the genus Lasiodiplodia, the species L. theobromae and L. pseudotheobromae were isolated as causative agents of soursop rot. Both species have similar morphological characteristics, such as the appearance of mature conidia with thick walls and longitudinal striations, forming melanin on the surface of the inner wall [30]. It has been reported that the species Lasiodiplodia theobromae is more frequent and virulent compared to other genera and species of the Botryosphaericeae family; this may be due to the pathogen/host interaction. It has been reported that this family has LA-SOL3 as the primary signaling 
gene to identify and infect a wide range of host plants and proliferate under different conditions. Besides, it has HSP genes that protect cells from possible damage caused by thermal stress factors [31].

Paolinelli et al. [32] showed that the genes related to the catabolism of pectins, starch, and sucrose, as well as the interconversion pathways of pentose and glucuronate were induced in Lasiodiplodia theobromae during the process of infection of grapes. Additionally, they related the production of these enzymes with the cell wall degradation of the plants and the salicylic acid synthesis, resulting in the defense of the host.

On the other hand, the genus Fusarium has a wide distribution in the world, besides having agricultural and economic importance. It is mainly distributed in cultivated soils where they break down cellulosic plant material.

The species of the genus Fusarium cause diseases in the plants such as vascular wilts, spots and leaf blots, rot of roots and stems, the rot of fruits, grains, and seeds [33]. Within this genus, there is a great diversity of forms, and they are characterized by being pathogenic during storage, saprophytes, and biocontrollers; they usually invade from the harvest $[11,25,33]$. Fusarium species infect important crops such as soft and hard wheat, barley, oats, rice, corn, potatoes, asparagus, mango, grasses, and other foods [34]. Besides, Fusarium fungi produce a variety of mycotoxin types [35]. Cambero et al. [29] reported to Fusarium sp. as soursop pathogen in pre-harvest.

Fusarium solani (anamorph), also known for its teleomorphic state (Nectria haematococca Berk), is one of the fungi most frequently isolated from soil and plant material, where these fungi act as decomposers, but they are also host-specific pathogens of various plants (sweet potatoes, curcubitáceas, and peas) and fruits (melon, papaya, eggplant, cucumber, squash sponge and tomato) being of great agricultural importance $[25,36]$. Furthermore, Hernández-Guerrero et al. [37] isolated and identified the pathogen N. haematococca in soursop fruits using morphological and molecular tools. Indeed, Rubio-Melgarejo et al. [38] showed that $N$. haematococca attacks soursop fruits and stimulates the antioxidative system during ripening. Fusarium chlamydosporum, F. wollenwebe, and F. reinking species have also been identified as soursop pathogens [39].

Gliocladium is the cause of the disease known as fruit rot. This fungus has not been reported in Mexico as a soursop pathogen [40]. It has been recognized as a causative agent of green mold disease, affecting edible fungi such as Agaricus bisporus, Lentinula edodes, and Pleurotus ostreatus [19].

Some species of Gliocladium have been used as commercial biocontroller strains of the genera Alternaria, Botrytis, Didymella, Fusarium, Pythium, Phytophthora, Rhizoctonia, and Sclerotinia in plants [41]. However, in this work, it was found as a pathogen of the soursop fruit.

In Mexico, Rhizopus sp. causes soft rot in Annonaceae; it is a disease of considerable importance, generating 50\% of losses in Mexico [2,29]. A representative species of the Rhizopus genus is R. stolonifer Ehrenb. (Ex Fr.) Lind, which is considered as one of the main phytopathogens that cause postharvest diseases. It is the causative agent of soft rot of fruits and vegetables, causing significant economic losses [42]. However, Rhizopus oryzae has been reported as a pathogen of the soursop fruit, being registered for the first time by Palemón et al. [43].

The fungus Colletotrichum spp is the most common in tropical fruits, in particular, the species C. gloeosporioides, causing deterioration in Annonaceae, by direct penetration of the shell, causing the disease known as anthracnose in the fruit, mentioned by Hernández et al. [1], Andrades et al. [10], Cambero et al. [29] and Nweke et al. [44]. Thus, affecting its commercialization and reducing the value of the product and preventing its export.

Due to the above, the incidence and pathogenicity of the genera Fusarium sp, Rhizopus, Lasiodiplodia, Gliocladium, and Colletotrichum, especially the species Lasiodiplodia pseudotheobromae, Lasiodiplodia theobromae and Nectria haematococca in soursop fruits, could be demonstrated. 
The fungi with the highest degree of pathogenicity were those found in the common of Tonino, located in the municipality of Compostela, Nayarit; this may be because the orchard is in the most top production area of soursop in Nayarit, Mexico, which could give the fungus a higher possibility to adapt and infect the fruit. Likewise, Talamantes et al. [45] mention that the soursop crop has low genetic diversity in the municipality of Compostela, Nayarit, Mexico, which may be related to a susceptibility of the plant to isolates of the genus Lasiodiplodia; it could explain that L. theobromae fungi and L. pseudotheobromae were the most pathogenic species towards the soursop fruits and were obtained from the three sampling areas, regardless of the environmental characteristics and agronomic management of the crop.

Another variable to consider is that the soursop fruit is climacteric, which is characterized by its high respiration rate and ethylene production, showing a short postharvest shelf life [8]. It should be noted that the pulp consists mainly of water, non-reducing sugars, and carbohydrates [46], which makes it susceptible to attack by microorganisms. Therefore, it is essential to regulate the agronomic management of each of the orchards [3,40]. That is why pre-harvest management plays a critical role in pathogen reduction. Besides, climatic and crop conditions (variety in cultivars, fertilizer application, soil type, among others) can determine the susceptibility of the fruits to diseases, ripening, handling, and storage [47]. Another factor to consider is that the period of the highest production of the fruit is in the months July, August, and September, which, in the Nayarit state, is the rainiest period, which makes it more susceptible to attack by pathogens and can generate high losses economics in soursop crops of up to $50 \%$ to $100 \%[1,10]$.

The fungal contamination of the fruits during the postharvest is mainly due to the fruit handling system during the harvest, the transfer to the packing machine, in the packaging, during storage, transport, and distribution to the commercialization centers, where can occur mechanical damage on fruits and facilitate the entry of pathogens into the mesocarp [48], causing postharvest losses of up to $40 \%$ in developing countries [49].

Taking this into account, it is essential to characterize these pathogenic fungi in soursop fruits, to subsequently implement a training program for the personnel in charge of the management of the orchards and postharvest management through brochures, interviews, courses, among others, which would enhance the potential of growth and exploitation of the crop. Therefore, this would be reflected in the national and international production system, improving the socio-economic conditions of the producers, and developing new technologies.

\section{Conclusions}

The Lasiodiplodia, Colletotrichum, Rhizopus, Fusarium, and Gliocladium genera were identified as potential pathogens of the soursop fruit. Molecularly, the species Nectria haematococca, Lasiodiplodia theobromae, and Lasiodiplodia pseudotheobromae were identified, which presented the highest pathogenic capacity. Lasiodiplodia is the main fungi found in soursop during postharvest.

Author Contributions: Conceptualization, P.U.B.-R.; methodology, Y.A.P.-H.; validation, V.A.O.-J. and P.P.C.-J.; formal analysis, G.B.-V.; investigation, G.G.L.-G.; writing-original draft preparation, A.V.G.-R.; writing—review and editing, V.A.O.-J.; visualization, P.P.C.-J.; supervision, G.B.-V.; project administration, R.B.-M. and P.U.B.-R.; funding acquisition R.B.-M. and P.U.B.-R. All authors have read and agreed to the published version of the manuscript.

Funding: This research was funded by Fondo Sectorial de Investigación en materias agrícolas, pecuaria, acuacultura, agrobiotecnología y recursos fitogenéticos SADER-CONACyT, grant number 266891. "Aprovechamiento del germoplasma, desarrollo tecnológico e innovación en cadenas de valor de Anonáceas en México".

Institutional Review Board Statement: Not applicable.

Informed Consent Statement: Not applicable. 
Data Availability Statement: The data used to support the findings of this study are available from the corresponding author upon request.

Acknowledgments: The authors want to thank the National Council of Science and Technology (CONACyT) for the Master's scholarship granted to Alejandra Verónica González-Ruíz (No. 605493).

Conflicts of Interest: The authors declare no conflict of interest. The funders had no role in the design of the study; in the collection, analyses, or interpretation of data; in the writing of the manuscript, or in the decision to publish the results.

\section{References}

1. Hernández, L.; Gómez, R.; Agustín, J. Importancia de las Plagas Insectiles y Enfermedades Fungosas del Cultivo Del Guanábano. IntechOpen Publishing Inifap. 2013. Available online: http://inifapcirpac.gob.mx/publicaciones_nuevas/ Importancia, \%20plagas\%20insectiles\%20y\%20enfermedades\%20fungosas\%20del\%20cultivo\%20del\%20Guanabano.pdf (accessed on 18 May 2019).

2. SIAP. 2019. Available online: https:/ / nube.siap.gob.mx/cierreagricola/ (accessed on 10 January 2019).

3. Hernández, L.; Moctezuma, H.; Martínez, N.; Bello, R.; Rocha, D.; Contreras, R. La situación de las annonaceae en México: Principales plagas, enfermedades y su control. Rev. Bras. Frutic. 2014, 36, 44-54. [CrossRef]

4. Vinay, G.; Sakthivel, T.; Priyanka, H. Recent Advances in Annona Breeding: A Review. Int. J. Pure App. Biosci. 2017, 5, 1168-1181. [CrossRef]

5. Janick, J.; Paull, R.E. The Encyclopedia of Fruit \& Nuts; CABI: Manoa, HI, USA, 2008.

6. Hernández, L.; Nolasco, Y.; Cruz, E. Selección y Caracterización de Guanábana y Recomendaciones Para su Manejo Agronómico. IntechOpen. 2017. Available online: http://biblioteca.inifap.gob.mx:8080/jspui/bitstream/handle/123456789/4419/4720\% 20Slecci $\%$ C3\%B3\%20y\%20caracterizaci $\%$ C3\%B3n \%20de $\% 20$ guan $\%$ C3\%A1bana $\% 20 y \% 20$ recomendaciones $\% 20$ para $\% 0$ su $\% 20$ manejo\%20agron\%C3\%B3mico.pdf?sequence=1 (accessed on 10 January 2019).

7. Coria, A.; Montalvo, E.; Obledo, E. Soursop (Annona muricata). In Fruit and Vegetable Phytochemicals: Chemistry and Human Health, 2nd ed.; Yahia, E., Ed.; Wiley: New York, NY, USA, 2017; pp. 1243-1251.

8. Berumen-Varela, G.; Hernández-Oñate, M.A.; Tiznado-Hernández, M.E. Utilization of biotechnological tools in soursop (Annona muricata L.). Sci. Hortic. 2019, 245, 269-273. [CrossRef]

9. Cayeros, S.E.; Robles, F.J.; Jiménez, A. Guanábana en el municipio de Compostela, Nayarit. Educateconciencia $2017,13,27-36$.

10. Andrades, I.; Yender, F.; Labarca, J.; Ulacio, D.; Paredes, C.; Marín, Y. Evaluación de la antracnosis (Colletotrichum sp.) en guanábana (Annona muricata L.) tipo Gigante en el sector Moralito del estado Zulia, Venezuela. Rev. UDO Agric. 2009, 9, 148-157.

11. Agrios, G.F. Fitopatología, 2nd ed.; Ed. Limusa: Cd de México, México, 1999.

12. Barnett, H.L.; Hunter, B. Illustrated Genera of Imperfect Fungi, 4th ed.; APS Press: St. Paul, MN, USA, 1998.

13. Watanabe, T. Pictorial Atlas of Soil and Seed Fungi: Morphologies of Cultured Fungi and Key to Species; CRC: Boca Raton, FL, USA, 2010; in press.

14. Benbow, J.M.; Sugar, D. Fruit surface colonization and biological control of postharvest diseases of pear by preharvest yeast applications. Plant Dis. 1999, 83, 839-844. [CrossRef] [PubMed]

15. Allers, T.; Lichten, M. A method for preparing genomic DNA that restrains branch migration of Holliday junctions. Nucleic Acids Res. 2000, 28, 1-22. [CrossRef] [PubMed]

16. Phillips, A.J.; Alves, A.; Abdollahzadeh, J.; Slippers, B.; Wingfeld, M.; Groenewald, J.Z.; Crous, P.W. The Botryosphaeriaceae: Genera and species known from culture. Stud. Micol. 2013, 76, 51-167. [CrossRef] [PubMed]

17. Costa, A.; Menezes, M. Identification and pathogenic characterization of endophytic species from cowpea sedes. AAPCA 2006, 3 , 203-215.

18. Sreekanth, D.; Sushim, G.K.; Syed, A.; Khan, B.M.; Ahmad, A. Molecular and Morphological Characterization of a Taxol-Producing Endophytic Fungus, Gliocladium sp., from Taxus baccata. Microbiology 2011, 39, 151-157. [CrossRef]

19. Castillo, H.; Rojas, R.; Villalta, M. Gliocladium sp., agente biocontrolador con aplicaciones prometedoras. Rev. Tecnol. Marcha. 2016, 29, 57-64. [CrossRef]

20. Arauz, L.F. Fitopatología: Un Enfoque Agroecológico, 1st ed.; Editorial Universidad de Costa Rica; UCR: San José, SJ, Costa Rica, 2011.

21. Picos, P.A.; García, R.S.; León, J.; Sañudo, A.; Allende, R. Lasiodiplodia theobromae en Cultivos Agrícolas de México: Taxonomía, Hospedantes, Diversidad y Control. Rev. Mex. Fitopatol. 2015, 33, 54-74.

22. Chethana, C.; Chowdappa, P.; Pavani, K.; Biju, C.; Praveena, R.; Sujatha, A. Morphological and multi-loci gene analysis of five species of Colletotrichum responsible for anthracnose on black pepper in South India. Int. J. Adv. Biotechnol. Res. 2015, 6, 327-342.

23. Weir, B.S.; Johnston, P.R.; Damm, U. The Colletotrichum gloeosporioides species complex. Stud. Mycol. 2012, 73, 115-180. [CrossRef]

24. Trigos, Á.; Ramírez, K.; Salinas, A. Presencia de hongos fitopatógenos en frutas y hortalizas y su relación en la seguridad alimentaria. Rev. Mex. Mic. 2008, 28, 125-129.

25. Pitt, J.; Hocking, A. Fungi, and Food Spoilage; Springer Nature: Boston, MA, USA, 2009.

26. Damm, U.; Cannon, P.; Crous, P. The Colletotrichum boninense species complex. Stud. Mycol. 2012, 73, 1-36. [CrossRef]

27. Netto, S.B.; Assuncao, I.P.; Lima, S.A.; Marques, M.W.; Lima, W.G.; Monteiro, H.A.; de Queiroz, B.V.; Michereff, S.J.; Phillips, J.L.; Camara, P.S. Species of Lasiodiplodia associated with papaya stem-end rot in Brazil. Fungal Divers. 2014, 67, 127-141. [CrossRef] 
28. Chávez, M.; Espinosa, K.; Vázquez, L. Lasiodiplodia theobromae en la atmósfera de La Habana. RCCB 2016, 5, 130-134.

29. Cambero, C.B.; Luna, G.; Rios, C.; Díaz, M.; Rodríguez, M.; Betancourt, A.; Cambero, O.J. Causal agents of rot in Soursop fruit (Annona muricata L.) in Nayarit, Mexico. Rev. Bio. Cienc. 2019, 6, 1-13. [CrossRef]

30. Alves, A.; Crous, P.W.; Correia, A.; Phillips, A. Morphological and molecular data reveal cryptic speciation in Lasiodiplodia theobromae. Fungal Divers. 2008, 28, 1-13.

31. Félix, C.; Meneses, R.; Gonçalves, M.F.; Tilleman, L.; Duarte, A.S.; Jorrín, J.V.; Van de Peer, Y.; Deforce, D.; Van Nieuwerburgh, F.; Esteves, A.; et al. A multi-omics analysis of the grapevine pathogen Lasiodiplodia theobromae reveals that temperature affects the expression of virulence-and pathogenicity-related genes. Sci. Rep. 2019, 9, 1-12. [CrossRef] [PubMed]

32. Paolinelli, M.; Villalobos, J.; Rolshausen, P.; Herrera, A.; Galiendo, C.; López, J.; Hernandez, R. Global transcriptional analysis suggests Lasiodiplodia theobromae pathogenicity factors involved in modulation of grapevine defensive response. BMC Genom. 2016, 17, 615. [CrossRef]

33. Arbeláez-Torres, G. Algunos aspectos de los hongos del genero Fusarium y de la especie Fusarium oxysporum. Agron. Colomb. 2000, $17,11-22$.

34. Glenn, A.E. Mycotoxigenic Fusarium species in animal feed. Anim. Feed Sci. Technol. 2007, 137, 213-240. [CrossRef]

35. Nesic, K.; Ivanovic, S.; Nesic, V. Fusarial Toxins: Secondary Metabolites of Fusarium Fungi. In Reviews of Environmental Contamination and Toxicology, 1st ed.; Whitacre, D.M., Ed.; Springer: Basilea, Switzerland, 2014; pp. 101-120.

36. Naureen, Z.; Price, A.H.; Wilson, M.J.; Hafeez, F.Y.; Roberts, M.R. Suppression of rice blast disease by bioantagonistic bacterial strains isolated from the rice grown in Pakistan. Crop Prot. 2009, 28, 1052-1060. [CrossRef]

37. Hernández-Guerrero, S.E.; Balois-Morales, R.; Bautista-Rosales, P.U.; López-Guzmán, G.G.; Berumen-Varela, G.; PalominoHermosillo, Y.A.; Jiménez-Zurita, J.O.; Bello-Lara, J.E.; León-Fernandez, A.E. Identification of Fungal Pathogens of Mango and Soursop Fruits Using Morphological and Molecular Tools and Their Control Using Papaya and Soursop Leaf and Seed Extracts. Int. J. Agron. 2020, 2020, 8962328. [CrossRef]

38. Rubio-Melgarejo, A.; Balois-Morales, R.; Ochoa-Jiménez, V.A.; Casas-Junco, P.P.; Jiménez-Zurita, J.O.; Bautista-Rosales, P.U.; Berumen-Varela, G. Differential Responses of Antioxidative System during the Interaction of Soursop Fruits (Annona muricata L.) and Nectria haematococca at Postharvest Storage. Plants 2021, 10, 1432. [CrossRef]

39. Alberto, R.T.; Otanes, A.T. Morphological and molecular identification and fungicide sensitivity assay of pathogens attacking guyabano (Annona muricata) in Philippines. Plant Pathol. Quarant. 2016, 6, 60-79. [CrossRef]

40. Ploetz, R.C. Diseases of Tropical Fruit Crops; CABI: Egham, UK, 2003.

41. Helyer, N.; Cattlin, N.D.; Brown, K.C. Biological Control in Plant Protection: A Colour Handbook; CRC Press: Boca Raton, FL, USA, 2014.

42. Velázquez-del Valle, M.G.; Bautista, S.; Hernández, A.N.; Guerra, M.G.; Amora, E. Estrategias de control de Rhizopus stolonifera Ehrenb. (Ex Fr.) Lind, agente causal de pudriciones postcosecha en productos agrícolas. Rev. Mex. Fitopatol. 2008, $26,49-55$.

43. Palemón, F.; Cruz, B.; Reyes, G.; Damián, A.; Toribio, J.; Romero, Y.; Vargas, D.; Bello, J. First report of Rhizopus soft rot on soursop (Annona muricata) caused by Rhizopus oryzae in México. J. Plant Dis. Protec. 2019, 127, 275-277. [CrossRef]

44. Nweke, C.N.; Ibiam, O.F. Pre and postharvest fungi associated with the soft rot of the fruit of Annona muricata and their effects on the nutrient content of the pulp. Am. J. Food Nutr. 2012, 2, 78-85. [CrossRef]

45. Talamantes, C.A.; Cortés, M.; Balois, R.; López, G.; Palomino, Y.A. Análisis molecular de la diversidad genética en guanábana (Annona muricata L.) mediante marcadores SRAP. Rev. Fitotec. Mex. 2019, 42, 209-214. [CrossRef]

46. Jiménez, J.O.; Balois, R.; Alia, I.; Juárez, P.; Jiménez, E.I.; Sumaya, M.T.; Bello, J.E. Tópicos del manejo poscosecha del fruto de guanábana (Annona muricata L.). Rev. Mex. Cienc. Agric. 2017, 8, 1155-1167. [CrossRef]

47. Ochoa, J.; Hernández, L.; Latisnere, H.; León de la Luz, J.; Larrarlde, C. Aislamiento e identificación de hongos patógenos de naranja Citrus sinensis L. osbeck cultivada en Baja California Sur, México. Cienc. Tecnol. Aliment. 2007, 5, 352-359. [CrossRef]

48. González, R.; Blancas, F.; Velázquez, R.M.; Montaño, B.; Ramos, A.; Aguirre, L.; Moreni, C.; Coronado, L.; Herrera, J.; Rodriguez, C.; et al. 2019 Alternative Eco-Friendly Methods in the Control of Post-Harvest Decay of Tropical and Subtropical Fruits. In Modern Fruit Industry. IntechOpen. Available online: https:/ /www.intechopen.com/online-first/alternative-ecofriendly-methods-in-the-control-of-post-harvest-decay-of-tropical-and-subtropical-fr (accessed on 18 May 2019).

49. Mohamed, Z.; AbdLatif, I.; Mahir Abdullah, A. 1-Economic importance of tropical and subtropical fruits. In Woodhead Publishing Series in Food Science, Technology and Nutrition, 3rd ed.; Elhadi, M.Y., Ed.; Woodhead Publishing: Sawston, UK, $2011 ;$ pp. 1-20. 